\title{
How to Deal With Economic Divergences in EMU?
}

\author{
Catherine Mathieu* and Henri Sterdyniak*
}

\begin{abstract}
Since the launch of the euro, persistent and even rising disparities among member states have made it difficult to implement short-term or structural common economic policies. The article gives an overview of Euro area disparities in terms of growth and inflation and imbalances, mainly unemployment and current accounts. Four explanations are considered: the benefits of the single currency for catching-up countries, the weaknesses of the Euro area economic policy framework; the implementation of non-cooperative domestic policies which have induced excessive competition and insufficient coordination and hurt mainly the larger economies; and the crisis of the European continental model in a global world. Four strategies are discussed: increasing market flexibility; moving towards the knowledge society of the Lisbon Agenda; re-nationalising economic policies; and introducing a more growth-oriented policy framework.

JEL classification: E6I

Keywords: European economy, policy-mix, European social model
\end{abstract}

\section{Introduction}

Before the launch of the euro, the proponents of European economic and monetary Union (EMU) thought that the single currency would pave the way for rapid economic convergence among member states. Smaller country specificities would have reduced the need for domestic fiscal policies and the conduct of short-tem economic policy could have been handed over mostly to the European Central Bank (ECB). Fiscal binding rules would then have been justified. The macroeconomic success of EMU would have helped the convergence of industrial and social policies towards a liberal model (more labour market flexibility, more product competition, reduction of the role of the state and public sector and

* OFCE, Paris.

Correspondence address:

Dr. Catherine Mathieu, OFCE, 69 quai d'Orsay, 75007 Paris, France, e-mail: catherine.mathieu@ sciences-po.fr

Received 3I Jan 2007, accepted 28 Jun 2007

(C) INTERVENTION 4 (2), 2007, 28I-307 
less welfare spending). In return, the successes of these structural policies would have facilitated the coordination of stabilisation policies.

But there have been persistent and sometimes growing divergences between the Euro area countries in terms of output growth, inflation, unemployment and external balances since 1999. The single currency tends to impose similar macroeconomic policies in countries in different situations and seems to have widened growth disparities among Member States. The launch of the single currency made winners (Ireland, Spain, Greece) and losers (Germany, Italy, the Netherlands, Portugal). The institutions and the rules set out by the Treaties (the ECB, the Stability and Growth Pact [SGP]) have been unable to tackle these divergences. European institutions have tried to introduce structural reforms (through the broad economic policy guidelines [BEPGs], the open method of coordination [OMC], or the Lisbon Agenda), but have faced national specificities or inertia. Their implementation has been lacking democratic legitimacy, lacking support at the domestic level and not always been in line with domestic policy decisions.

In most economies and especially in the bigger ones, the introduction of the euro did not result in the promised acceleration of output growth. In some countries, the acceleration of growth generated hardly sustainable imbalances. Member states have been unable to set out a common growth strategy. They have not questioned the ECB's remit and SGP rules. Euro area countries, with the exception of Ireland, are widely homogeneous in terms of high taxation rates and Bismarckian social protection systems. However they have been unable or unwilling to maintain this specificity at the European level. They have hesitated between two strategies: a social-Keynesian one with a strong commitment to maintaining a specific European Social Model (ESM) and a proactive industrial policy; a free market strategy, based on market deregulation and reform of the ESM through public expenditures cuts and a smaller role of the state in the economy. European institutions recommended liberal strategies that did not always meet people's expectations, albeit lacking the democratic legitimacy needed to impose such measures. This weakened the European construction. The move towards more flexible markets has been questioned (for instance with the non-adoption of the so-called Bolkestein Directive). Some countries were tempted to re-nationalise industrial policy (like in France for instance), while most European countries opposed the implementation of European social or fiscal policies. This debate takes place at a time when European continental countries especially need to adapt to globalisation: Should they move towards a liberal or a Scandinavian model? Should this choice be made at the European or at national levels?

Section 2 provides an overview of disparities in terms of output growth, inflation and unemployment in the Euro area. The widening of some economic imbalances (current account and government deficits, competitiveness) and the persistence of disparities are highlighted. Section 3 addresses four reasons for persistent and rising disparities: the benefits of the Euro area for catching-up countries; the weaknesses of the Euro area economic policy framework; the implementation of non-cooperative domestic policies which have induced excessive competition, insufficient coordination and have been detrimental mainly to the larger economies; and the crisis of the continental model in a global world. 
Section 4 discusses strategies aiming at reducing disparities in Europe: increasing market flexibility; moving towards the knowledge society of the Lisbon Agenda; re-nationalising economic policies at the domestic level; or introducing a more growth-oriented European economic policy framework.

\section{Euro Area: Disparities and Lost Illusions}

GDP growth was relatively satisfactory in the Euro area countries between 1985 and 199I (+3.I percent per year, see table I). GDP growth decelerated by I.3 percentage points per year from 1992 to 1998 due to a bad management of the German reunification and to contractionary fiscal policies implemented in the convergence process to meet the Maastricht criteria. The launch of the single currency in 1999 did not enable the area to reach a more satisfactory growth. Since 1991, GDP has grown less rapidly in the Euro area than in the UK or in the US (I.8 percent per year, versus respectively 2.7 and 3.3).

Table I: GDP Growth Rates and GDP Per Capita

\begin{tabular}{l|ccc|cc}
\hline & \multicolumn{3}{|c|}{ \%, per year } & \multicolumn{2}{c}{ PPP GDP per capita } \\
& Euro area $=100$ \\
& $1985-1991$ & $1992-1998$ & $1999-2005$ & 1991 & 2005 \\
\hline Euro area & 3.1 & 1.8 & 1.9 & 100.0 & 100.0 \\
\hline Belgium & 2.7 & 1.8 & 2.0 & 108.7 & 111.1 \\
\hline Germany & 3.5 & 1.5 & 1.3 & 108.9 & 101.5 \\
\hline Greece & 1.7 & 1.8 & 4.3 & 67.0 & 78.9 \\
\hline Spain & 3.9 & 2.3 & 3.6 & 79.2 & 92.8 \\
\hline France & 2.6 & 1.8 & 2.2 & 104.2 & 102.7 \\
\hline Ireland & 4.0 & 7.2 & 6.5 & 78.8 & 130.6 \\
\hline Italy & 2.9 & 1.3 & 1.2 & 105.3 & 97.6 \\
\hline Netherlands & 3.6 & 2.7 & 1.7 & 107.0 & 117.4 \\
\hline Austria & 3.1 & 2.2 & 2.0 & 113.8 & 114.8 \\
\hline Portugal & 5.1 & 2.4 & 1.6 & 68.6 & 67.2 \\
\hline Finland & 1.8 & 2.5 & 2.8 & 97.6 & 108.7 \\
\hline Denmark & 1.5 & 2.7 & 1.9 & 106.7 & 116.2 \\
\hline Sweden & 1.9 & 2.7 & 2.9 & 108.2 & 111.6 \\
\hline UK & 2.6 & 2.7 & 2.7 & 93.6 & 110.4 \\
\hline US & 2.8 & 3.6 & 3.0 & 131.1 & 139.7 \\
\hline
\end{tabular}

Source: European Commission (statistical annex of European Economy) 
Since 1999, GDP growth has remained strong in Ireland and has accelerated in two countries only: Spain and Greece, although this has led to a rise in current account deficits. Looking at average GDP growth rates in 1999-2005 and 1985-1991, the main losers are Germany, Italy, Portugal, and the Netherlands. Greece and Spain have been converging towards the area average in terms of GDP per head (in PPP), while Portugal and Italy have been diverging downwards and Ireland upwards: In I4 years (from I99I to 2005), the GDP per capita relative to the Euro area rose by 65 percent in Ireland, I8 percent in Greece, I7 percent in Spain whereas it declined by 1.5 percent in Portugal. Among the largest economies, the GDP per capita relative to the Euro area declined by 7 percent in Germany and Italy, and by I.5 percent in France, whereas it rose by I8 percent in the UK. Non-Euro area EU countries performed better than Euro area ones.

Many economists argue that Euro area growth is low because potential growth is low and disparities in domestic GDP growth rates reflect disparities in domestic potential growth (see, for instance, Benalal et al. 2006). According to the European Commission and OECD estimates, the Euro area potential growth rate was two percent between 1998 and 2005, hence very close to observed growth rates. From that point of view, if demand had been more robust, the outcome would have been higher inflation only. Inflation has remained almost stable in the Euro area since 1996, which would mean that demand was roughly equal to potential output, either by chance or thanks to an appropriate monetary policy. Output could have been increased only through structural measures: higher productivity growth (owing to capital accumulation, higher R \& D or education spending), higher labour supply (through immigration, longer working time and lower female and older people inactivity rates), or a lower equilibrium unemployment rate (through increased labour market flexibility). In our view, however, output growth is not determined by but has an impact on productivity gains, capital accumulation, participation rates, equilibrium unemployment rates and even population (through immigration). What does "potential growth « mean for countries suffering from mass unemployment and low participation rates? When unemployment rates are high, older people and female participation rates decrease, either without or with policy; companies have no incentive to raise labour productivity. Thus contractionary fiscal policies, high real interest rates or low competitiveness may induce low output growth for several years. This will not reflect low potential growth that would materialise independently of observed growth. Saying that weak past observed growth is due to low trend growth, can be a self-fulfilling prophecy if it is taken as a basic assumption by economic policy.

From 1998 to 2005, unemployment rates decreased slightly in the majority of Euro area countries but rose in Germany, Portugal, and also in the Netherlands and Austria, although remaining at a low level (see table 2). Unemployment rates fell rapidly in four countries: Ireland and Finland, thanks to robust GDP growth, Italy thanks to low labour productivity growth, ${ }^{\mathrm{I}}$ Spain thanks to both growth and low labour productivity growth. However, in 2005, eight Euro area countries remained in a mass unemployment situa-

I This is probably partly a statistical artefact resulting from the regularisation of foreign workers and the reduction of labour in the underground economy. 
tion. These countries account for 90 percent of the area and they could have tried to introduce policies to support growth and employment, especially as inflation was moderate (2.2 percent) and the current account was in balance. But the priority was instead to implement structural reforms.

Table 2: Unemployment and Employment Rates

\begin{tabular}{l|cc|c|c}
\hline & Unemployment rate, \% & $\begin{array}{c}\text { Employment rate, \% } \\
\text { (full time } \\
\text { equivalent) }\end{array}$ & $\begin{array}{c}\text { Labour productivity } \\
\text { growth rate, } \\
\text { \% per year } \\
\text { 1999-2005 }\end{array}$ \\
\hline Euro area & 1998 & 2005 & 2005 & 1.0 \\
\hline Belgium & 10.1 & 8.6 & 59.8 & 1.2 \\
\hline Germany & 9.3 & 8.4 & 57.1 & 1.6 \\
\hline Greece & 8.8 & 9.5 & 60.4 & 3.5 \\
\hline Spain & 10.9 & 9.8 & 59.2 & 0.3 \\
\hline France & 15.0 & 9.2 & 60.9 & 1.1 \\
\hline Ireland & 11.1 & 9.5 & 59.7 & 2.8 \\
Italy & 7.5 & 4.3 & 64.6 & 0.4 \\
\hline Netherlands & 11.3 & 7.7 & 55.5 & 1.3 \\
\hline Austria & 3.8 & 4.7 & 60.9 & 1.5 \\
\hline Portugal & 4.5 & 5.2 & 63.7 & 0.8 \\
\hline Finland & 5.1 & 7.6 & 65.6 & 1.5 \\
\hline Denmark & 11.4 & 8.4 & 65.3 & 1.6 \\
\hline Sweden & 4.9 & 4.8 & 69.4 & 1.9 \\
\hline UK & 8.2 & 7.8 & 68.0 & 1.7 \\
US & 6.1 & 4.7 & 65.4 & 2.2 \\
\hline & 4.5 & 5.1 & 67.0 & \\
\hline
\end{tabular}

Source: OECD Employment Outlook

In terms of employment rates, Italy stands clearly below the other Euro area countries. Belgium comes next. The other countries can be split into two groups: medium rate countries (Germany, Greece, Spain, France and the Netherlands) and high rate countries (Ireland, Austria, Portugal, Finland and, outside the area, Sweden, Denmark and the UK). High rate countries include Scandinavian and liberal countries and also Austria. Medium rate countries would have to increase their employment rates by almost ten percent to reach the UK level (I8 percent for Italy). This will be a challenge for economic policies in the years to come, especially in the prospect of financing higher pension expenditures. However, a crucial issue remains: Should demand be increased first in order to increase labour demand, hoping that labour supply will follow? Structural reforms like the abolition of early retirement or a better control of unemployment allowances would be implement- 
ed only ex post and only in countries where labour demand is clearly above supply. Such a strategy would raise a risk of inflationary pressures. Or should countries where unemployment is high start with structural reforms which would raise labour supply and employment? Such a strategy would provoke the risk of raising unemployment and increasing poverty among the unemployed.

Many countries suffering from high unemployment rates have chosen to give company incentives to reduce labour productivity growth and to hire unskilled workers (Spain, Italy, Belgium and France). Other countries (Germany) tried instead to increase employment through competitiveness gains, especially through higher productivity growth in the industry. The European employment strategy and the Lisbon Agenda failed to impose a common strategy.

A good functioning of the monetary union requires avoiding disparities in terms of price levels. Different price levels will generate competitiveness differentials and will need to be corrected later through output growth differentials. In practice, inflation differentials have remained substantial in the Euro area (see table 3 ). Countries running higher inflation were mainly catching-up ones, with higher output growth and low initial price levels, due to the Balassa-Samuelson effect (Greece, Ireland, Spain, Portugal). However, Italy and the Netherlands also had relatively high inflation rates. The Dutch economy ran above capacity for several years and inflation was increased by several rises in indirect taxes. Inflation was not due to excessive demand levels induced by excessive public deficits in any of these countries. Even when accounting for the Balassa-Samuelson effect, which may explain one percentage point of inflation in Greece, 0.7 percentage points in Portugal and 0.5 percentage points in Spain (for a discussion, see ECB 2003), prices seem to have risen too rapidly in these three countries and this has led to price competitiveness losses. Inflation has been extremely low in Germany, which has prevented other countries from restoring their price competitiveness. In 2006, inflation disparities remained large in the Euro area: inflation was 0.9 percent in the three countries running the lower inflation, and 3.2 percent in the countries running the higher inflation. Wage and price formation processes have not converged yet.

Another difficulty in a monetary union is that catching-up countries have structurally higher output growth and inflation rates than more "mature« countries. Thus it is difficult to run a single monetary policy even in the absence of asymmetric shocks. With a single nominal interest rate, Euro area countries have had different real interest rates corrected for growth (see table 3). The single monetary policy was contractionary for Germany and expansionary for Ireland, Greece and Spain where companies and households had a strong incentive to borrow and invest, which boosted domestic GDP growth and inflation.

The Euro area interest rate was 3.I percent on average from 1999 to 2005 . A Taylor rule based on an inflation target of 2 percent, output gaps as estimated by the OECD, ${ }^{2}$ would have suggested average interest rates of 1.75 percent for Germany, 3.05 percent for France, 3.8 percent for Italy, 4 percent for the Euro area, and 8.05 percent for Spain. However the

2 The rule is defined as: $\mathrm{i}=2+0.5(2-\pi)+0.5$ gap, where $\mathrm{i}$ is: central bank's interest rate, $\pi$ : inflation, gap: output gap as estimated by the OECD. 
Table 3: Inflation and Real Interest Rates

\begin{tabular}{l|c|c|cc}
\hline & Price level & $\begin{array}{c}\text { Inflation, \% per year } \\
\text { (GDP deflator) }\end{array}$ & \multicolumn{2}{|c}{$\begin{array}{c}\text { Real interest rate less GDP } \\
\text { growth rate percentage points }\end{array}$} \\
\hline Euro area & $\mathbf{2 0 0 5}$ & $1999-2005$ & $1992-1998$ & $1999-2005$ \\
\hline Belgium & 100.0 & 1.8 & 2.5 & -0.6 \\
\hline Germany & 104.9 & 1.7 & 1.6 & -0.6 \\
\hline Greece & 81.4 & 0.7 & 1.6 & 1.1 \\
\hline Spain & 88.6 & 3.6 & 6.7 & -3.3 \\
\hline France & 103.8 & 3.9 & 2.1 & -4.4 \\
\hline Ireland & 116.3 & 1.4 & 2.9 & -0.5 \\
\hline Italy & 97.3 & 3.9 & -3.5 & -7.3 \\
\hline Netherlands & 103.5 & 2.5 & 3.9 & -0.6 \\
\hline Austria & 101.9 & 2.7 & 0.9 & -1.4 \\
\hline Portugal & 81.5 & 1.5 & 1.3 & -0.4 \\
\hline Finland & 109.5 & 3.4 & 1.6 & -1.7 \\
\hline Denmark & 129.7 & 1.2 & 1.3 & -0.9 \\
\hline Sweden & 112.1 & 2.3 & 2.5 & -0.9 \\
\hline UK & 105.5 & 1.4 & 1.7 & -0.8 \\
\hline US & 93.9 & 2.5 & 3.7 & 0.3 \\
\hline & & 2.2 & -0.1 & -2.4 \\
\hline
\end{tabular}

Source: European Commission (statistical annex of European Economy)

2 percent inflation target may be judged too low. The Euro area needs higher GDP growth and this may result in transitory inflationary pressures on some markets. The OECD potential output estimates are very low: The Euro area output gap was estimated to be zero in 1999 , when the unemployment rate was 9.2 percent and zero also in 2002, when the unemployment rate was 8.3 percent.

The ECB is less concerned with GDP growth than the Fed in good and in bad times. Since 1999, the monetary stance has been clearly more expansionary than suggested by a Taylor rule in the US; more accommodative in the Euro area too, although to a smaller extent, and restrictive in the UK (see table 4, p. 288).

The wage share in GDP decreased both at the Euro area level and in eight member states between 1999 and 2005 (see table 5, p. 288). Real wages increased by a mere 0.35 percent per year in Germany, 0.5 percent in Austria and Italy, o.6 percent in Belgium, while they rose by I.3 percent in France, I.5 percent in the Netherlands and 2.5 percent in the UK. Increasing company profitability and price competitiveness through downwards pressure on wages became a major strategy in several countries, like in Germany and Austria. On the one hand, it was the only tool available for countries which could neither depreciate 
Table 4: Taylor Rules and Effective Central Bank Rates (\%)

\begin{tabular}{l|cccccccc}
\hline & 1999 & 2000 & 2001 & 2002 & 2003 & 2004 & 2005 & 2006 \\
\hline $\begin{array}{l}\text { Euro area } \\
\begin{array}{l}\text { Taylor based } \\
\text { rate }\end{array}\end{array} \quad 2.5$ & 4.8 & 5.3 & 4.55 & 3.55 & 3.75 & 3.5 & 3.7 \\
$\begin{array}{l}\text { Actual rate } \\
\text { UK }\end{array}$ & 3.1 & 4.5 & 4.3 & 3.3 & 2.3 & 2.1 & 2.2 & 3.1 \\
$\begin{array}{l}\text { Taylor based } \\
\text { rate }\end{array}$ & 3.2 & 3.05 & 3.45 & 3.3 & 3.4 & 3.5 & 4.0 & 4.05 \\
$\begin{array}{l}\text { Actual rate } \\
\text { US }\end{array}$ & 5.6 & 6.2 & 5.0 & 4.1 & 3.7 & 4.6 & 4.8 & 5.0 \\
$\begin{array}{l}\text { Taylor based } \\
\text { rate }\end{array}$ & 4.6 & 7.15 & 5.2 & 2.75 & 3.75 & 4.8 & 6.35 & 6.15 \\
Actual rate & 5.4 & 6.5 & 3.8 & 1.8 & 1.2 & 1.6 & 3.5 & 5.2 \\
\hline
\end{tabular}

Note: The rule is defined as: $\mathrm{i}=2+0.5(2-\pi)+0.5$ gap, where $\mathrm{i}$ is: central bank interest rate, $\pi$ : inflation, gap: output gap as estimated by the OECD.

Source: Own calculations based on OECD Economic Outlook data.

their currency nor cut their interest rate nor use fiscal policy once the 3 percent of GDP limit for government deficits had been breached. On the other hand, firms could threaten to relocate their production abroad in order not to raise wages. Last, fixed exchange rates (at least in the Euro area) ensured that the effect of wage moderation would not be cancelled by exchange rate appreciation. This strategy helped exports but put a drag on private consumption in the countries where it was implemented and consequently dampening demand in the whole Euro area.

Table 5: Adjusted Wage Share in GDP, 1998-2006

\begin{tabular}{l|c}
\hline & $\begin{array}{c}\text { Change in } \\
\text { percentage points, } \\
\text { 1998-2006 }\end{array}$ \\
\hline Euro area & -2.1 \\
Belgium & -2.0 \\
\hline Germany & -2.6 \\
\hline Greece & -3.8 \\
\hline Spain & -4.5 \\
\hline France & 0.5 \\
\hline Ireland & -1.9 \\
\hline Italy & -0.5 \\
\hline
\end{tabular}

\begin{tabular}{l|c}
\hline & $\begin{array}{c}\text { Change in } \\
\text { percentage points, } \\
\text { 1998-2006 }\end{array}$ \\
\hline Netherlands & -1.7 \\
\hline Austria & -5.8 \\
\hline Portugal & 3.7 \\
\hline Finland & -0.3 \\
\hline Denmark & -2.3 \\
\hline Sweden & 1.7 \\
\hline UK & 3.1 \\
\hline US & -1.0 \\
\hline
\end{tabular}

Source: European Commission (statistical annex of European Economy) 
In this non-cooperative game, Germany, Austria and the Netherlands succeeded in supporting their GDP growth through a positive contribution of net exports (by around o.5 percentage point of GDP per year, see table 6). On the contrary, Spain and France suffered from a negative external contribution ( 0.7 percentage points of GDP per year).

Consumption growth was weak in Germany, the Netherlands, Belgium and Austria from 1999 to 2005 . In some countries (Germany, Austria) housing investment fell abruptly in parallel, whereas housing booms developed in Spain and Ireland with the support of low real interest rates. In Germany, the weak level of households' demand was not offset by a rise in company investment. Company investment rose rapidly in catching-up countries (Greece, Spain).

Table 6: GDP and Domestic Demand Growth Rates, I999-2005

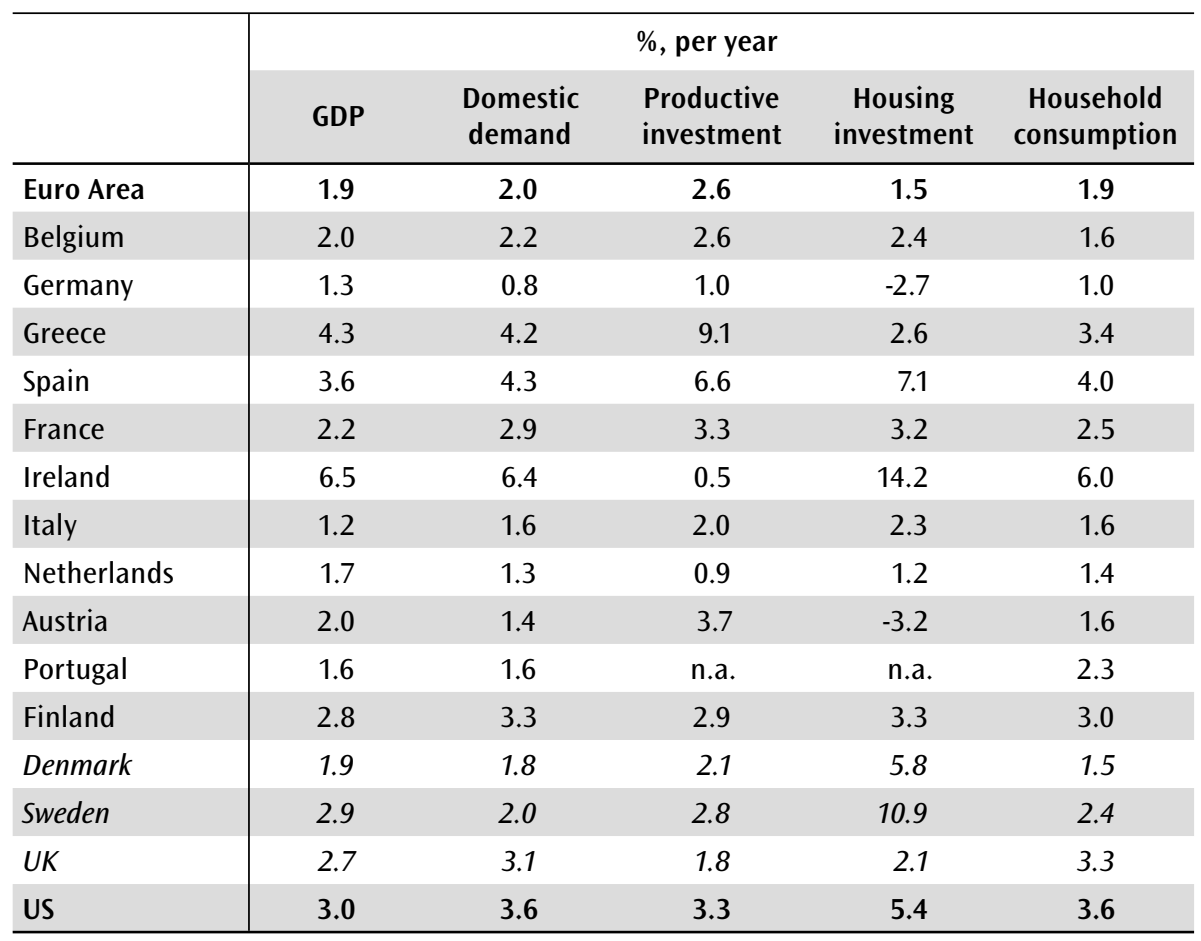

Source: European Commission (statistical annex of European Economy)

In terms of domestic and external demand, Euro area countries can be divided into four groups: the "winners" (Ireland, Spain, Greece), where both domestic and external demand is strong; the »bad guys" (Germany, Austria, Netherlands), where a weak domestic demand is offset by strong export demand gains; the »losers" (Italy, Portugal) suffering from both low domestic and external demand; the "victims" (France, Belgium, Finland) where a weak external demand partly offsets a satisfactory domestic demand. 
The Euro area as a whole won competitiveness from 1996 to $200 \mathrm{I}$ thanks to the fall in the euro vis-à-vis the US dollar. A weak euro together with the new information and communication technology bubble accompanied strong GDP growth (three percent per year from 1997 to 2000) and employment (8.7 percent in five years). This shows that the European economy can grow rapidly if there is robust demand. The competitiveness gains were more than cancelled by appreciation of the euro vis-à-vis the US dollar and Asian currencies from 200I and 2004. Therefore, the Euro area needs a weaker exchange rate in the light of the high level of unemployment. The Euro area has been able to have a low exchange rate only when domestic demand was strong in the US, because the US then also had an interest in a high dollar. But the euro vis-à-vis the US dollar is always high when US domestic demand is relatively weak. The Euro area also suffers from a less active monetary policy than in the US. Last, the Euro area suffers from exchange rate policies in Asian countries, where exchange rates are kept low to support fragile GDP growth (Japan), to support export growth (China, new industrial economies) and to accumulate foreign currency reserves.

From 1988 to 1999, some European countries had succeeded in depreciating their currency in real terms vis-à-vis the Deutsche Mark: Finland, Italy, Spain and, outside the future Euro area, Sweden. Germany, Austria and Portugal joined the Euro area at too high exchange rates, which induced substantial current account deficits. Since 1999, Austria and Germany have succeeded in restoring their competitiveness through wage moderation policies. Italy seems to be unable to maintain its competitiveness in the absence of exchange rate devaluation. Italy and Portugal have been more affected than the average area by the emergence of China.

Fixed exchange rates and rigid inflation rates induce persistent exchange rates misalignment periods. In the Euro area countries can no more devalue their currency to restore their competitiveness. Wage moderation policies are the only tool left but take a long time to play and are painful, since they depress demand both at home and in the area. Wage moderation policies would be all the more difficult to implement in Euro area countries because they are already implemented in Germany, where domestic inflation is very low which makes it harder for partner countries to gain competitiveness against Germany.

Non-coordinated policies have increased imbalances within the Euro area: In 2005, a few countries ran substantial current account surpluses: the Netherlands (6.6 percent of GDP) and Germany (4.2 percent), whereas some others ran large deficits: Portugal ( -9.3 percent of GDP), Spain ( -7.4 percent), and Greece ( -7.9 percent) (see table 7$)$. The I6o billion euro surplus of Germany and the Netherlands finances the I 45 billion euro deficit of the Mediterranean countries. Do these divergences in current accounts reflect an equilibrium process (older countries' savings being invested in younger and more profitable countries) or a disequilibrium one (European savings being spoiled in non-profitable investment, such as housing, in Southern countries)? This situation cannot be considered as optimal since real interest rates corrected for output growth differ across the area. Deficits can widen because they are not financed by financial markets but by transfers within the European banking system and hence can hardly be visible. Foreign direct invest- 
ments (FDI) cover only a small part of these deficits: Portugal receives a small amount of net FDI (I percent of GDP in 2005), but net FDI are negative for Spain (-I.4 percent of GDP) or Greece (-0.4 percent). National saving rates are very low in Greece, Spain and Portugal which is unusual for countries growing at a rapid rate.

Output growth is strong in Greece, Spain, the UK and in the US too, while both national and households saving rates are very low. On the contrary, Belgium, Germany, Austria and France suffer from too high saving rates. Low saving rates seem necessary to have high GDP growth and low public debt. Virtue is dangerous in Europe, since the weakness of domestic demand resulting from a high savings ratio cannot be offset by low interest rates or substantial government deficits.

Table 7: External Positions and Savings Ratios

\begin{tabular}{l|cc|cc|c|c}
\hline & \multicolumn{2}{|c|}{ Competitiveness } & \multicolumn{2}{|c|}{$\begin{array}{c}\text { Current account } \\
\text { balance, \% of GDP }\end{array}$} & $\begin{array}{c}\text { National } \\
\text { savings rate } \\
(\%)\end{array}$ & $\begin{array}{c}\text { Household } \\
\text { net savings } \\
\text { ratio (\%) }\end{array}$ \\
\hline Euro Area & 1998 & 2005 & 1998 & 2005 & 2005 & 2005 \\
\hline Belgium & 108 & 100 & $\mathbf{0 . 8}$ & $\mathbf{0 . 0}$ & $\mathbf{2 0 . 6}$ & n.a. \\
\hline Germany & 104 & 96 & 5.2 & 2.5 & 23.7 & 6.2 \\
\hline Greece & 101 & 109 & -0.8 & 4.2 & 22.1 & 10.7 \\
\hline Spain & 89 & 77 & -3.0 & -7.9 & 15.8 & n.a. \\
\hline France & 108 & 95 & -1.2 & -7.4 & 16.9 & 5.4 \\
\hline Ireland & 101 & 100 & 2.6 & -1.7 & 19.9 & 11.6 \\
\hline Italy & 92 & 107 & 0.8 & -2.6 & 25.5 & n.a. \\
\hline Netherlands & 114 & 95 & -3.0 & -1.1 & 20.5 & 9.5 \\
\hline Austria & 105 & 96 & 3.2 & 6.6 & 24.0 & 5.7 \\
\hline Portugal & 95 & 114 & -3.1 & 1.2 & 22.7 & 9.5 \\
\hline Finland & 97 & 73 & -7.1 & -9.3 & 15.7 & 4.9 \\
\hline Denmark & 127 & 122 & 5.6 & 5.2 & 19.0 & n.a. \\
\hline Sweden & 101 & 89 & -0.9 & 2.9 & 23.8 & -5.8 \\
\hline UK & 110 & 132 & 3.9 & 6.0 & 22.9 & n.a. \\
\hline US & 92 & 86 & -0.4 & -2.2 & 15.4 & 0.0 \\
\hline & 94 & 108 & -2.4 & -6.4 & 14.5 & -0.4 \\
\hline
\end{tabular}

I $1988=$ I00; on the basis of unit labour costs in the manufacturing sector.

A rise means competitiveness gains. Italic numbers: non-Euro area EU-I5 members

(Denmark, Sweden, UK).

Source: OECD Economic Outlook

In the last recession (2000-2004), GDP growth was hardly supported by fiscal policies in the Euro area: the fiscal impulse was I.2 percentage points of GDP only, as compared to 
5.6 percentage points in the UK and six percentage points in the US (see table 8). Except for Greece and Finland, Euro area countries implemented close to neutral fiscal policies. These years of low growth and rising fiscal deficits generated tensions between European authorities and national governments. In 2005, five Euro area countries and seven nonEuro area countries were under an excessive deficit procedure (EDP) (Mathieu/Sterdyniak 2006). The SGP was a corset for fiscal policies in these years. The objective of bringing debts to below 60 percent of GDP was not fulfilled: Government debts still stand at around Ioo percent of GDP while the French and German debts have risen above 60 percent of GDP.

\section{Table 8: Fiscal Policies}

\begin{tabular}{l|cccc}
\hline & \multicolumn{4}{|c}{ As a percentage of GDP } \\
& $\begin{array}{l}\text { Government } \\
\text { balance, 2005 }\end{array}$ & $\begin{array}{c}\text { Fiscal impulse } \\
\text { 2000/2004 }\end{array}$ & $\begin{array}{c}\text { Gross public } \\
\text { debt, Maastricht } \\
\text { definition, 2005 }\end{array}$ & $\begin{array}{c}\text { Net public debt, } \\
\text { 2005 }\end{array}$ \\
\hline Euro Area & -2.4 & 1.2 & 71 & 55 \\
\hline Belgium & 0.0 & 0.6 & 93 & 86 \\
\hline Germany & -3.2 & 1.1 & 68 & 58 \\
Greece & -5.1 & 7.1 & 109 & 96 \\
\hline Spain & 1.1 & -0.4 & 43 & 31 \\
\hline France & -2.9 & 1.5 & 67 & 44 \\
\hline Ireland & 1.1 & 2.8 & 28 & 10 \\
\hline Italy & -4.3 & 2.4 & 106 & 39 \\
\hline Netherlands & -0.3 & 0.0 & 53 & 42 \\
Austria & 1.3 & -2.7 & 63 & 45 \\
\hline Portugal & -6.0 & 1.3 & 64 & -60 \\
\hline Finland & 2.5 & 4.9 & 41 & 7 \\
\hline Denmark & 4.6 & -0.4 & 36 & -12 \\
\hline Sweden & 2.8 & 3.1 & 50 & 41 \\
\hline UK & -3.4 & 5.6 & 44 & 46 \\
\hline US & -.3 .7 & 6.0 & 65 & 48 \\
\hline
\end{tabular}

I The fiscal impulse is the change in the primary cyclically adjusted government balance. A positive figure reflects an expansionary policy. Italic numbers: non-Euro area EU-Is members (Denmark, Sweden, UK).

\section{Source: OECD Economic Outlook}

However, public finances were more sustainable in the Euro area than in the US, the UK or Japan in 2006 (see table 9). Although public finances have deteriorated in the Euro area because of a persistent negative output gap, fiscal consolidation is not urgently need- 
ed in Euro area economies. European institutions put a too strong weight on public deficits relative to growth issues.

Table 9: Public Finance Sustainability in 2006

\begin{tabular}{l|c|c|cc}
\hline & \multicolumn{4}{|c}{ As a percentage of GDP } \\
& $\begin{array}{l}\text { Structural } \\
\text { deficit }\end{array}$ & Output gap & \multicolumn{2}{|c}{$\begin{array}{l}\text { Limit for government } \\
\text { deficit sustainability }\end{array}$} \\
& & & Strict & Soft \\
\hline US & 3.7 & 0.6 & 3.0 & 3.3 \\
\hline Japan & 5.3 & 0.5 & 1.0 & 3.0 \\
Germany & 2.1 & -1.7 & 1.7 & 2.7 \\
France & 2.1 & -1.7 & 1.8 & 2.8 \\
Italy & 3.6 & -1.3 & 1.9 & 4.3 \\
\hline Portugal & 2.8 & -4.1 & 2.3 & 4.0 \\
Greece & 3.5 & 1.2 & 3.3 & 7.0 \\
UK & 3.1 & -0.8 & 2.0 & 2.5 \\
\hline
\end{tabular}

I Government deficit is considered sustainable if the structural deficit is lower than desired public debt times the sum of potential output growth and targeted inflation. The limit for government balance is calculated under two criteria: a strict one, where the level of desired debt is either the current observed level or 50 percent of GDP (for countries where debt is above this limit); a softer criterion where the level of desired debt also corresponds to the observed level or 50 percent of GDP (for countries where debt is below this limit). Moreover, under the softer criterion, the structural balance is assumed to include discretionary measures for an amount in terms of GDP corresponding to 25 percent of the output gap, if the latter is negative. Public finances are unsustainable if the public deficit exceeds the

limit, even under the more favourable option: this is the case for countries in italics.

\section{Source: OECD Economic Outlook, own calculations}

The majority of Euro area countries, except Spain and Ireland, have high public expenditure levels, standing at above 50 percent of GDP. At the Euro area level, the share of primary structural public spending was the same in 1990 and 2006. The share has risen in several countries: Portugal (by ten percentage points), Belgium (3.5 percentage points) and France (2.5 percentage points) and, outside the Euro area, the UK ( 3 percentage points). The share has fallen in other countries: the Netherlands (by five percentage points), Spain (four percentage points), Ireland (2.5 percentage points), and also in Sweden (five percentage points). The European Commission has failed to impose public expenditure cuts in the European Union and countries have hardly converged. High levels of public expenditure require high levels of taxation. But, as the Scandinavian example shows, high tax-toGDP ratios are consistent with high employment rates (see figure I, p. 294). 
Figure I: Employment Rates and Taxation Rates



Source: OECD Revenue Statistics, Labour Force Statistics

The expression "European Social Model« is generally used to refer to an original economic and social framework in EU countries, but the content of this concept is vague. It is more a political objective - defining a minimum set of common characteristics among member states that the European construction would agree to defend. But European social protection systems differ in many respects. They are generally characterised according to four systems (Esping-Anderson 1990), even if this classification raises many issues:

- The Scandinavian model, with a very high level of social expenditure based on citizenship, funded through taxation, a high female employment rate, low social inequalities and a strong cooperation between social partners (Finland, the Netherlands and also Denmark and Sweden).

- The Continental model, with a high level of social expenditure based mostly on activity, financed by social contributions, a high level of labour protection (Germany, France, Belgium, Austria).

- The Mediterranean model with an intermediate level of social expenditure based on activity, financed by social contributions, a low level of family and unemployment benefits offset by family solidarity, low female participation rates, and a high level of labour protection (Italy, Greece, Spain, Portugal).

- The Liberal model with a low level of social expenditure, based on citizenship, targeting the poorer, and with a low level of labour protection (Ireland and also the UK). 
Replacement ratios derived from unemployment benefits are high in most Euro area countries, with the exception of the mediterranean ones (Spain, Greece, Italy), where unemployment rates are not particularly low. Employment protection is strong in continental and mediterranean countries, as compared to liberal and some Scandinavian countries (according to the OECD employment protection legislation [EPL] indicator, see table IO).

\section{Table Io : Employment Protection Indicators}

\begin{tabular}{lccc}
\hline & $\begin{array}{c}\text { Social protection public } \\
\text { expenditures, \% of GDP, 2005 }\end{array}$ & $\begin{array}{c}\text { Net replacement rate } \\
\mathbf{2 0 0 4}\end{array}$ & $\begin{array}{c}\text { EPL, } \\
\text { Be03 }\end{array}$ \\
\hline Belgium & 30.1 & 66 & 2.5 \\
\hline Germany & 30.2 & 75 & 2.5 \\
\hline Greece & 23.8 & 33 & 2.9 \\
\hline Spain & 22.1 & 52 & 3.1 \\
\hline France & 33.4 & 71 & 2.9 \\
\hline Ireland & 20.1 & 71 & 1.3 \\
\hline Italy & 20.9 & 6 & 2.4 \\
\hline Netherlands & 24.8 & 79 & 2.3 \\
Austria & 29.7 & 73 & 2.2 \\
\hline Portugal & 27.8 & 72 & 3.5 \\
Finland & 29.4 & 75 & 2.1 \\
\hline Sweden & 36.7 & 77 & 2.6 \\
UK & 26.3 & 66 & 1.1 \\
\hline Denmark & 34.3 & 77 & 1.8 \\
\hline Japan & 21.1 & 66 & 1.8 \\
\hline US & n.a. & 29 & 0.7 \\
\hline & & & \\
\hline
\end{tabular}

Source: OECD Employment Outlook

Table II (p. 296) summarises economic disparities in the Euro area in 2005. Until recently, European authorities have been focusing on public finance imbalances. But the weakness of GDP growth in Italy and Germany, the persistence of high unemployment rates in several Euro area countries, and competitiveness losses in southern economies as reflected in rising current account imbalances are more worrying for the Euro area as a whole.

Table I2 (p. 296)summarises the economic situation of EU-I5 countries using a global index of imbalances based on growth, inflation and unemployment rates and on public and external balances. Some countries have no major macroeconomic problem (Denmark, Sweden, the Netherlands, Finland, Austria, and Ireland). Some countries suffer mainly from insufficient GDP growth (Germany, France, Italy, Belgium, and Portugal). Some countries have mainly current account deficits problems (Spain, UK, Greece, and Portugal). The smaller countries seem to have performed better than the bigger ones, older 
Table II: Disparities in the Euro Area in 2005

\begin{tabular}{|c|c|c|c|c|}
\hline $\begin{array}{c}\text { GDP growth, } \\
\%\end{array}$ & $\begin{array}{l}\text { Unemployment } \\
\text { rates, } \\
\%\end{array}$ & $\begin{array}{c}\text { Inflation, } \\
\%\end{array}$ & $\begin{array}{l}\text { Current account } \\
\text { balance, } \\
\% \text { of GDP }\end{array}$ & $\begin{array}{c}\text { Government } \\
\text { balance, } \\
\% \text { of GDP }\end{array}$ \\
\hline $\begin{array}{c}>3: \\
\text { Ireland, Greece, } \\
\text { Spain }\end{array}$ & $\begin{array}{c}<5: \\
\text { Ireland, } \\
\text { Netherlands }\end{array}$ & $\begin{array}{c}<2 \text { : } \\
\text { Germany, Finland, } \\
\text { France, Austria }\end{array}$ & $\begin{array}{c}>3: \\
\text { Netherlands, } \\
\text { Germany }\end{array}$ & $\begin{array}{l}>0: \\
\text { Finland, Spain, } \\
\text { Ireland }\end{array}$ \\
\hline $\begin{array}{l}<2 \text { : } \\
\text { Italy, Germany, } \\
\text { Portugal, } \\
\text { Netherlands }\end{array}$ & $\begin{array}{l}\quad>8 \text { : } \\
\text { Greece, Germany, } \\
\text { France, Spain, } \\
\text { Belgium, Finland }\end{array}$ & $\begin{array}{c}>3 \text { : } \\
\text { Spain, Ireland, } \\
\text { Greece, Portugal }\end{array}$ & $\begin{array}{c}<-5: \\
\text { Spain, Portugal, } \\
\text { Greece }\end{array}$ & $\begin{array}{c}<-2 \text { : } \\
\text { Portugal, } \\
\text { Greece, Italy, } \\
\text { Germany, France }\end{array}$ \\
\hline
\end{tabular}

Source: European Commission (statistical annex of European Economy)

countries better than catching up ones, outside the Euro area better than Euro area countries. The Scandinavian model exhibits the best performance; the Mediterranean model the poorer one (see table i3).

Table I2: Economic Performance Disparities in the EU-IS

\begin{tabular}{l|lc}
\hline & & Index $^{1}$ \\
\hline Germany & Continental, big, old & -3.0 \\
\hline France & Continental, big, old & -4.0 \\
\hline Italy & Mediterranean, big, old & -5.3 \\
\hline Spain & Mediterranean, medium, catching-up & -3.3 \\
\hline Netherlands & Scandinavian, medium, old & 4.2 \\
\hline Belgium & Continental, small, old & -0.2 \\
\hline Austria & Continental, small, old & 3.8 \\
\hline Greece & Mediterranean, small, catching up & -6.3 \\
\hline Portugal & Continental, small, catching up & -7.2 \\
\hline Ireland & Liberal, small, catching up & 5.1 \\
\hline Finland & Scandinavian, small, old & 4.3 \\
\hline Denmark & Scandinavian, small, old & 5.5 \\
\hline Sweden & Scandinavian, small, old & 5.1 \\
\hline UK & Liberal, big, old & 1.4 \\
\hline US & Liberal, big, old & -1.8 \\
\hline
\end{tabular}

I The index is calculated as: $2 \mathrm{~g}-\mathrm{i}-(\mathrm{ur}-5)+0.5(\mathrm{sb}+\mathrm{eb})$, using $1999-2005$ data for GDP growth (g) and HICP inflation (i); 2005 data for unemployment rate (ur), public (sb) and current account (eb) balances. The higher the index, the better is the country's economic performance. 


\section{Table 13: Disequilibrium Index ${ }^{I}$}

\begin{tabular}{lr|lc}
\hline Big country & -2.5 & Small country & 1.3 \\
In the Euro area & -1.1 & Outside the Euro area & 2.6 \\
Old & 0.9 & Catching up & -3.0 \\
\hline
\end{tabular}

Performance according to the Social Model

\begin{tabular}{ll|llll|ll}
\hline Scandinavian & 4.8 & Continental & -0.9 & Mediterranean & -5.5 & Liberal & 1.6 \\
\hline
\end{tabular}

I Unweighted averages of the respective values in Table I2.

Source: Own estimates

\section{How to Explain Disparities in the Euro Area?}

Since 1999, a number of disparities and imbalances between countries have remained or increased in the Euro area. This is due to an economic framework which was not built to handle diverse and persistent structural disparities. Catching-up countries have benefited from low real interest rates. The absence of economic policy coordination is harmful especially for larger economies albeit allowing the smaller economies to take advantage of it. Economic policy does no more aim at supporting growth but at inducing structural reforms. Finally, continental countries are not prepared to address globalisation, having chosen neither a liberal strategy nor a Scandinavian one.

\section{I The Advantages of Being a Catching-up Country}

Catching-up countries have benefited from significant falls in their nominal interest rates from 1992 to 1999. Real interest rates adjusted for growth fell by Io points in Greece, 6.5 points in Spain, and 3.8 points in Ireland (see table 3). At the same time, the exchange rate risk disappeared. Households and company investment was boosted by interest rates. This raised output and inflation, lowering further real interest rates adjusted for growth (Deroose et al. 2004). Domestic output cannot be stabilised through the Euro area monetary policy. Losses in competitiveness are the only stabilising factor although it takes time to play. The rise in external deficits can be easily financed by the European banking system. Growth in catching-up countries has not decelerated despite rising external deficits because domestic demand robustness did more than offset competitiveness losses. The persistence of external deficits induces a progressive deterioration of households' and firms' debt ratios, which could initiate a financial crisis. But this risk is minor due to the low level of real interest rates. The rise in foreign borrowing does not lead to financial market prudence, because borrowing is in euros and hence there is no exchange risk. The relatively small size of catching-up countries means that domestic inflation, domestic credit and external deficits do not generate tensions at the Euro area level and can be accepted by other Euro area countries. Catching-up countries have therefore a strong advantage in being in the Euro area. 
If they wanted to restore their competitiveness, they would need to run restrictive fiscal policies - but European authorities cannot request such a policy from them because robust GDP growth allows for a fiscal surplus, like in Spain - or restrictive wage policies, difficult to implement under robust output growth. Restrictive fiscal and wage policies would negatively affect peer countries so the latter do not exert pressure for such policies to be implemented. Hence imbalances can grow and persist for a long time. The bubble burst in Portugal in 200I, but has not yet in Spain or Greece. The two latter countries still seemed to be in a favourable situation in 2006 .

\subsection{Weaknesses in the Euro Area Economic Policy Framework}

The Euro area economic policy framework is based on three pillars. First, the single monetary policy aims at price stability. Second, domestic fiscal policies are under the surveillance of European procedures requesting medium-term budgetary positions in balance, allowing only economic stabilisers to play and no discretionary policy. Third, a European strategy of structural and liberal reforms expected to raise medium-term growth, although this strategy is hardly implemented at the domestic level (Fitoussi/Le Cacheux 2004, Mathieu/Sterdyniak 2003 and 2006). No common short-term stabilisation policy is implemented at the area level. Last, there is no consensus in the EU on a macroeconomic strategy: some countries would favour a growth strategy supported by demand, while the European Commission and other countries favour a strategy based on structural reforms.

On the contrary, a global macroeconomic strategy should set out ambitious growth targets for each country, should keep interest rates low, should try to maintain a relatively low exchange rate level, and should let each country implement the fiscal policy needed to reach the desired level of output. Contractionary fiscal policies should be requested only in countries running excessive inflation (accounting for the Balassa-Samuelson effect), excessive external deficits or credit growth. Countries running excessive external deficits should implement wage moderation policies in order to restore their competitiveness, but this should be accompanied by interest rate cuts or wage increases or more expansionary fiscal policies in partner countries. In this framework, excessive inflation would signal specific supply problems in countries having robust demand. These countries could then fight these tensions without fearing insufficient demand. The needed reforms would become clear once tensions have actually emerged: insufficient capital stock, shortage of skilled labour in specific sectors. The experience shows that imbalances resulting from excessive labour demand can easily be tackled either through raising skills, labour market participation or immigration.

It is excess supply which is difficult to tackle. Structural reforms are much more difficult to implement when demand is too low. When there are few job offers, it is difficult to find incentives to bring inactive people to work; it is difficult to train the unemployed for jobs that do not exist; the weakness of investment reduces labour productivity growth; it is difficult to reorganise the productive structure when laid-off people will not easily find a new job; structural reforms increase economic uncertainty and therefore the savings rate, 
which dampens demand further. Public deficits must then support demand and this increases uncertainty. Output growth is then constrained by the weaknesses of both demand and supply.

According to this point of view, national governments do not have enough room for manoeuvre to support growth, while the policy framework weaknesses maintain low growth in the Euro area. But this view does not explain why some countries performed better than others.

\subsection{Non-cooperative National Policies}

In the absence of economic policy co-ordination, countries use the tools at their disposal. Fiscal policy remains effective but in an area with many countries, each country may be reluctant to use the fiscal policy tool: the positive effects on output will be shared with trade partners and in the end will be relatively weak for the initiating country. Fiscal policy is relatively effective in large countries and conversely restrictive fiscal policy is particularly costly. Large countries may also use their political weight to oppose the European Commission's requests of reducing their domestic fiscal autonomy. Fiscal policy is less powerful in smaller countries. These countries also have less political weight in face of the European Commission.

On the contrary, smaller countries can be tempted to improve their competitiveness through wage moderation, because the negative impact on domestic demand will be more than offset by external demand gains. Such strategies are more painful for larger countries. Besides, concerted wage negotiations between social partners are more common in smaller than in larger countries, which facilitates the implementation of wage moderation policies. Smaller economies may also more easily introduce tax competition policies because the gains from attracting foreign companies will exceed the revenue losses on the national tax base.

If countries act independently, the outcome will be a non-optimal Nash equilibrium with too restrictive wage and fiscal policies. There is too much competition and not enough cooperation in the Euro area. This coordination failure is harmful for the area as a whole, more for larger economies than for smaller ones (Le Cacheux 2004).

Moreover, not all countries are in a similar situation. Some countries (the Netherlands, Austria, and the Scandinavian countries) have a long tradition of wage agreements which may help to answer demand or supply shocks. But this is not the case in other countries, like in Italy. Italy can no more depreciate its currency to counter the effects of the emergence of China and other Asian competitors. Fixed exchange rates and rigid inflation rates induce persistent periods of low growth in some countries, while other countries can react faster, either because of their smaller size or of more rapid wage answers.

Non-cooperative strategies can be implemented and be successful at the national level, especially in smaller countries. The bigger Euro area economies initially opposed such strategies but had to follow later on, like Germany since 20oI, which depresses demand in the Euro area and strengthens the search for competitiveness gains. 
In practice, the larger countries have run relatively expansionary fiscal policies (Germany, France, Italy), and also Portugal and Greece. From 1998 to 2005 , restrictive wage policies have been implemented in large countries (Germany), medium-size countries (Spain), and smaller economies (Austria, Greece). Two smaller economies (Finland, Austria) have cut their tax-to-GDP ratios by a larger extent.

Large countries may be tempted to modify the functioning of their labour market, either by centralising wage negotiations, or by promoting wage and labour flexibility. But there is no evidence that labour market flexibility alone can keep an economy close to full employment in the absence of active macroeconomic policies (see the US example), or without benefiting from competitiveness gains, like in the smaller European economies.

Large countries (Germany, France, Italy) account for 65 percent of the Euro area population. They could thus try to impose their strategy. However, they have never firmly taken a common position. For instance, in the SGP reform debate in 2005, they have not imposed that capital expenditures should be deducted from public deficits in the assessment of the three percent of GDP threshold. Is this a sacrifice in favour of the European construction? Or is this a strategic choice of domestic authorities in order to implement at home unpopular structural reforms in the name of Europe?

\subsection{The Crisis of the European Social Model}

Tensions are exacerbated by the difficulties faced by "the European Social Model« in a global world. The Continental European model appears less efficient vis-à-vis globalisation than the Anglo-Saxon model or the Scandinavian one (Sapir 2005, Aiginger 2006).

Continental European countries traditionally shared specificities in terms of the role of the state in the economy, industrial policies, relationships between firms, banks and the state, firms' financing, and financial markets. These specificities have been implicitly given up in the context of financial globalisation and European construction, but a new coherent framework remains to be developed. For example, who controls large companies if the state or banks are no more involved? In theory, it should be financial markets, but what happens if they do not play this role? The withdrawal of the state or the banks in the economy leaves an empty space, which may be detrimental to companies' governance and innovating capacities.

Globalisation places continental European workers in competition with new member states and Asian workers. What strategy does Europe wish to implement in face of industrial job losses? Can Europe choose a two-pillar strategy: on the one hand subsidising higher education and R\&D in order to help the expansion of innovative and high value-added sectors; on the other hand subsidising a lower-productivity sector of services for private households? Can this be achieved without a dramatic rise in inequalities? Does Europe wish the winners of globalisation to compensate for the losers' losses (but this requires that the winners agree or are constrained to pay, more national solidarity or more tax harmonisation, two strategies which Europe currently opposes)? Could the Scandina- 
vian strategy, combining efforts on innovation and on re-qualification and social support of the unemployed, be applied in more open, heterogeneous and large countries?

The Continental European model must be adapted, but this raises conflicts of interest between social classes. This implies economic and social choices. European authorities do not help in the process, for instance when they restrict state aid to firms, imposing reforms expected to foster competition, prohibit fights against tax avoidance, and so on.

European dominant classes have not tried to protect the European Social Model. They took the opportunity of globalisation and of the single market to impose structural reforms in Europe, in particular public and welfare expenditure cuts and labour market flexibility. In their view, active macroeconomic policies cannot support output growth: people should understand that the only choice is to accept a liberal functioning of the economy or see capital flow towards more friendly countries. This is the famous TINA (There is no alternative strategy) of Margaret Thatcher. Without any long run coherent macroeconomic and social strategy, the continental countries are the losers of the European construction in a global world.

\section{Which Policy Answers?}

The Euro area as a whole suffers from insufficient growth and seems unable to cut mass unemployment. This is true especially for five countries accounting for 72 percent of the area: Germany, Italy, France, Belgium and Portugal. Six countries are however in a better position: Spain, Greece, Ireland, Netherlands, Austria, Finland, although two of them run large external deficits. The Euro area economic strategy should thus aim at increasing the output level and at reducing imbalances while accounting for disparities.

\section{I A Market-oriented View}

For many economists and for the European Commission (see, for instance, Tilford 2006 or Deroose et al. 2004), increasing flexibility in all markets will reduce disparities in Europe. The EU has been unable to organise a satisfactory coordination of economic policies. Instead of trying to improve the framework, the mainstream view refers to a Walrasian myth: If each economy were fully flexible (prices, wages, workers), there would be no need for economic policy and therefore no coordination problem. But the US example shows that this is an illusion: Economic policy is needed even in a flexible economy.

More flexible labour markets are not the panacea. Contrary to today's mainstream opinion, wage flexibility is not the answer to demand or supply shocks because it increases uncertainty and demand weakness.

International labour mobility should not be an objective in Europe as a tool to reduce unemployment. Governments cannot say to the unemployed: »Please go and find a job abroad." The EMU should allow each country to grow, without having to ask people to emigrate (or even leave their region) to find a job. 
Under liberal strategies, the European Social Model necessarily moves towards the Anglo-Saxon one. In the absence of tax harmonisation, member states will have no choice but to cut strongly public expenditure and redistribution. If firms are allowed to earn profits in Germany and pay (reduced) taxes in Switzerland, who will pay for public infrastructure in Germany? If firms can chose to pay for workers' insurance in a private insurance company, who will pay for the poor? Continental European countries are supposed to have no choice but accept rising inequalities.

\subsection{The Lisbon Strategy}

The European Commission does not recommend an entirely liberal strategy, but a mix of sound macroeconomic policies, higher market flexibility, social protection reforms in order to raise employment, public support for innovation and a move towards a knowledge society. This strategy is embedded in the Lisbon Agenda and raises implementation and content issues.

The Lisbon strategy was a technocratic project from the beginning, without democratic debate, without mobilisation of the European opinion, involvement of the civil society and social partners. The strategy did not account for country differences, necessary trade-offs between objectives, and differences of views among social forces. The majority of the objectives of the Lisbon Agenda are related to research, innovation, higher education and have little impact for the majority of people. Short-term issues have been neglected. Last, the Lisbon Agenda raises the political issue of who should manage the reform process: the European Commission, national governments, national parliaments, social partners, or the public opinion?

A Sound Macroeconomic Strategy? We will consider here the latest version of the Lisbon Agenda, adopted in July 2005: the 24 integrated guidelines for growth and jobs (2005-2008).

Six macroeconomic guidelines recall the need for sound macroeconomic policies to support growth. Guidelines I and 6 repeat that countries must have medium-term budgetary positions in balance. Countries running deficits should cut their structural deficits by at least 0.5 percentage points per year, whatever the cyclical situation. The link between the single monetary policy and national fiscal policies is not considered. Guideline 2 asks member states to address the issue of ageing population by reducing public debt (but population ageing involves a rise in the savings rate, therefore the demand for public bonds), to reform their pensions and health systems (but how?) and finally to raise employment rates. But the strong growth strategy needed to reach these aims is not organised.

Guideline 3 requests public expenditure to be reallocated towards research, infrastructure and education. However the needed cuts in current expenditure are not specified. Guideline 4 requests that member states introduce structural reforms to facilitate the implementation of sound macroeconomic policies. But one could prefer that coordinated 
expansionary macroeconomic policies are implemented first in order to facilitate the implementation of structural reforms.

Microeconomic Strategy: Competition and Innovation ... The core objective of the Lisbon strategy is to raise productivity and innovation in Europe. EU-I5 GDP per capita has remained at 72 percent of US GDP per capita since 1973. This is more primarily due to differences in employment rates, unemployment rates and annual worked hours rather than to productivity per capita. But labour productivity per hour growth has kept on decelerating in the EU-I5 (one percent per year) since 1995 whereas it has accelerated in the US (2.2 percent per year). Innovations reducing the need for labour are hardly welcome in a mass unemployment situation.

The lessons of the burst of the NICT bubble and the collapse in equity prices are still to be drawn. Growth through innovation (guideline 8), ICT (guideline 9), development and liberalisation of financial markets remains the dogma. Guideline Io recommends strengthening the "competitive advantages of the industrial base«. But this would require a major change in the competition policy of the European Commission, which aims at reducing state aid.

Guideline II considers environmental issues, but contradictions between growth and environment are not highlighted. Guideline 12 recommends deepening the internal market. Here, too, contradictions are not accounted for: Should the energy sector and collective transportation system be privatised without considering long-term and regional planning issues? The questions raised by the Bolkestein Directive are not addressed: How should companies with different social standards compete? Guideline I3 calls for open and competitive markets; asks for the reduction of state aid which distorts competition, while recognising the need for addressing market deficiencies, helping research, innovation, and education. Guideline I4 calls for reducing regulations as if they were necessarily harmful. For example, should consumer protection be given up? Guideline 15 asks for fostering entrepreneurship, for instance by »a tax system that rewards success", which questions tax progressiveness.

What Employment Strategy? The Myth of Flexibility The general objective remains to increase labour force availability and quality. But no suggestion is made on how to increase job offers. Guideline 17 reaffirms ambitious objectives for employment rates (in 20IO, 70 percent for overall population, 60 percent for women, 50 percent for older workers). Guideline I8 suggests increasing labour demand by lowering youth unemployment, giving women and older people incentives to work. Guideline is recommends increasing work incentives. But the call for modernising social protection systems is worrying, if the point is to reduce early retirement, cut pensions or unemployment benefits while job opportunities for older workers are not there yet.

Guideline 20 proposes to remove obstacles to labour mobility, but sensitive issues are not addressed: How to prevent workers from Central and Eastern European countries from exerting downward pressure on wages in the West? Guideline 2I recommends in- 
creasing flexibility (albeit reconciling it with job security), anticipating better future changes and facilitating transitions. But which strategy should be implemented? Should it be Anglo-Saxon or Scandinavian?

Guideline 22 proposes to ensure that wages grow in line with productivity and that non-wage costs are cut, especially for the low-paid. Wages tend to grow already less rapidly than labour productivity in the Euro area: The wage share in value added dropped from 67.4 percent in 2000 to 66.2 percent in 2005 . Social contributions cuts cannot imply benefits cuts (what would be the advantage for workers and jobs to cut health contributions if this meant they would have to pay for private insurance?). Other resources should be found.

The Integrated Guidelines Forget Several Things The integrated guidelines forget that Europe suffers from insufficient demand which partly results from the European framework. They do not try to make the SGP consistent with the Lisbon Agenda, accounting for investment expenditure and more generally expenditure for the future, in the assessment of domestic fiscal policies. Monetary policy and more especially exchange rate policies are not considered. Can the Euro area remain competitive after a 40 percent rise in the euro vis-à-vis the US dollar? The guidelines do not consider social Europe. How to reconcile freedom of movement and establishment with domestic tax autonomy? How to avoid a "race to the bottom " tax competition? How to avoid a rising gap between the winners of globalisation refusing to contribute to national solidarity and the poorer? The guidelines do not consider industrial policy. Are competition policy and cuts in state aid sufficient? Should European champions and innovative sectors be supported? What policy answers in face of delocalisation?

\subsection{Less Europe? The Re-nationalisation of Economic Policies}

The re-nationalisation strategy would consist of giving back national governments room for manoeuvre to implement specific economic strategies. Each country could thus take care of solving its specific imbalances in its own way. The European economic policy framework would be re-examined with a view to leave more autonomy to member states. The latter would be allowed to implement domestic industrial policies, to protect their tax revenues through measures fighting tax avoidance, to choose their social model, etc. Governments (and the citizens) would be clearly responsible for their choices.

However, Euro area member states would continue to share a common monetary policy, interest rate and exchange rate. A code of good conduct would still need to be defined in order to avoid excessive inflation rates or external deficits. The countries would thus not be able to choose their policy mix. It would be difficult to re-nationalise the external trade policy. The prospect of future tax or social harmonisation would vanish. Re-nationalisation would increase the risk of implementation of non-cooperative strategies and of social and tax dumping. The countries would have no choice but move towards the liberal model. Europe would give up the ambition of offering a specific model. 


\subsection{More Europe?}

European countries have no other choice but to design a new economic policy framework, at least for the Euro area, if not for the EU-27. This framework must, at the same time, match democratic principles and account for diverse national situations.

A first option would be for economic policy to be decided at the Euro area level. But Europe is not a nation: Political, economic and social lives are not unified. Institutions, taxation and social protection systems differ. Economic circumstances themselves remain different. Some convergence would be necessary, but there are three models in Europe: Liberal, Scandinavian, and Continental. Towards which model should Europe converge? There is no consensus on economic policies, reforms, strategies or institutions in the Euro area. Choices can only result from a democratic process. But European peoples would probably not agree on an economic, political and social unification decided at the European level. It is difficult to imagine a single framework able to manage all different national situations. However, this is the case for monetary policy. But monetary policy only sets a single interest rate and we have seen that the outcome is not optimal. A European fiscal policy would have to set many tax rates, public expenditure levels, etc., which seems impossible.

European governance will need to be based on the coordination of national policies. The Euro area seems more appropriate for such a coordination than the EU-27 because it covers more homogenous economies. But this requires that member states agree to share a common »European Social Model« that will need to be defined, protected, and able to evolve.

However, the economic policy to be implemented remains a difficult issue (see, also, Huffschmid 2006) and will have to combine Keynes, Colbert and social democracy.

In a mass-unemployment situation, the Euro area needs a growth-oriented policy. It would be desirable to set up actual economic policy coordination in the framework of the Euro group, with whom the ECB would have to enter into a dialogue. This coordination should not focus on public finance balances, but should aim at supporting economic activity and achieving a three percent annual growth target. The process will have to account for the needs for growth in each country and also for their competitiveness, external balance and inflation rate. Intra-zone disparities should be accounted for: Catchingup countries could run higher inflation, high saving rates countries could be entitled to higher public deficits, some countries should be asked to raise taxes in order to avoid overaccumulating private debt, a depreciation of the euro could be preferred to national competitive policies, etc. ... This is not an easy task.

Europe should try to design a specific model of European firms, caring about jobs, regional activity and sustainable growth. Companies have a social role to play. They should care about not only their shareholders but also their employees and customers. This means that member states should maintain a relatively high level of company taxation to give companies incentives: by building homogeneous infrastructure in the country, subsidising firms locating their production in areas in difficulty, supporting economic sectors in difficulty and subsidising $R \& D$. Member states should have an active industrial policy, 
aiming both at developing large European companies and innovating small and medium enterprises (SME), research centres and companies networks. This would require the adoption of a common strategy in Europe. European authorities should plan their future productive activities and industrial employment in Europe; reduce the weight of competition policy and promote a European industrial policy in the framework of the Lisbon strategy. This common strategy should be implemented mainly by member states and not by European authorities. Cooperation in R \& D and higher education should be developed. But member states are not ready to give up their prerogatives because it is not immaterial for them whether education or research centres develop in their countries or abroad. Community rules need to be modified, so that domestic aid can support specific sectors.

The objective should be to maintain the European Social Model, characterised by a significant level of transfers, public expenditure and thus of taxation. Tax and social competition should be avoided. Some harmonisation will be needed to prevent unfair competition, through the introduction of minimum tax rates (corporate income, wealth and higher household incomes) and minimum benefits (minimum income, minimum pension replacement ratio) and by tough measures against tax evasion at a worldwide level. The European Social Model will have to rely on its comparative advantages (free education and health for all, good quality public infrastructure, efficient social security benefits) to remain competitive in a global world. A stronger GDP growth would lower unemployment rates and would allow the introduction of a "flexicurity system " in the continental countries, with an adequate support of the unemployed (vocational training, training for new jobs).

The improvement of the European economic framework is not only a technical issue; it requires a major change in economic policy thinking, a new alliance between social classes concerned about full employment and social cohesion, the willingness to depart from financial markets' and multinational companies' points of view. A prerequisite would be that member states' populations agree on a European model, but we are far from there.

\section{References}

Aiginger, Karl (2006): The Ability of Different Types of Socio-Economic Models to Adapt to New Challenges, presentation at the NERO meeting on the political economy of structural policy reform, I2 June 2006

Ahearne, Alan/Pisani-Ferry, Jean (2006): The Euro: Only for the Agile, Bruegel Policy Brief, No. I

Alesina, Alberto/Perotti, Roberto (2004): The European Union: A Politically Incorrect View, in: Journal of Economic Perspectives, Vol. I8, No. 4, pp. 27-48

Benalal, Nicholai/Diaz del Hoyo, Juan Luis/Pierluigi, Beatrice/Vidalis, Nick (2006): Output Growth Differentials Across the Euro Area Countries: Some Stylised Facts, ECB Occasional Papers, No. 45

Deroose, Servaas/Langedijk, Sven/Roeger, Werner (2004): Reviewing Adjustment Dynamics in EMU: From Overheating to Overcooling, European Commission Economics Papers, No. 198 
Duval, Romain/Elmeskov, Jorgen (2006): The Effects of EMU on Structural Reforms in Labour and Product Markets, ECB Working Paper, No. 596

ECB (2003): Inflation Differentials in the Euro Area: Potential Causes and Policy Implications, Frankfurt: European Central Bank

Esping-Andersen, Gosta (I990): The Three Worlds of Welfare Capitalism, Princeton: Princeton University Press

Fitoussi, Jean-Paul/Le Cacheux, Jacques (2004): Rapport sur l'Etat de l'Union européenne, Paris: Fayard

Huffschmid, Jörg (2006): Economic Policy for the European Social Model, in: Hein, Eckhard/Heise, Arne/Truger, Achim (eds.), European Economic Policies - Alternatives to Orthodox Analysis and Policy Concepts, Marburg: Metropolis, pp. 283-30I

Lane, Philip R. (2006): The Real Effects of EMU, IIS Discussion Paper, No. II5

Le Cacheux, Jacques (2005): Politiques de Croissance en Europe, un Problème d'Action Collective, in: Revue Économique, Vol. 56, No. 3, pp. 705-714

Mathieu, Catherine/Sterdyniak, Henri (2003): Réformer le Pacte de Stabilité : l'État du Débat, in: Revue de l'OFCE, No. 84, pp. I45-179. In English: Reforming the Stability and Growth Pact, Document de travail de l'OFCE

Mathieu, Catherine/Sterdyniak, Henri (2006): A European Fiscal Framework Designed for Stability or Growth?, in: Hein, Eckhard/Heise, Arne/Truger, Achim (eds), European Economic Policies - Alternatives to Orthodox Analysis and Policy Concepts, Marburg: Metropolis, pp. 4I-67

Mongelli, Francesco Paolo/Vega, Juan Luis (2006): What Effect is EMU Having on the Euro Area and its Member Countries? An overview, ECB Working Paper, No. 599

Saint-Paul, Gilles (2004): Why are European Countries Diverging in their Unemployment Experience?, in: Journal of Economic Perspectives, Vol. 18, No. 4, pp. 49-68

Sapir, André (2005): Globalization and the Reform of European Social Models, Bruegel Policy Brief, No. I

Tilford, Simon (2006): Will the Eurozone Crack?, London: Centre for European Reform Wyplosz, Charles (2005): European Monetary Union: The Dark Sides of a Major Success, in: Economic Policy, Vol. 2I, No. 46, pp. 207-262 
